Viewpoints and Letters to the Editor are published in HortScience to provide members of the American Society for Horticultural Science an opportunity to share their experiences and comments on matters of concern to horticulturists. These are not statements of official Society policy nor do they necessarily reflect the views of a majority of the Society's Members.

\title{
Caution Required in Distribution of Plants of Red Stele (Phytophthora fragaiae Hickman) -Resistant Strawberries
}

\author{
Shahrokh Khanizadeh ${ }^{1}$ \\ Agriculture Canada Research Station, 430 Boulevard Gouin, St-Jean-sur-Richelieu, Que. J3B 3E6, Canada \\ Deborah Buszard ${ }^{2}$ \\ Faculty of Agricultural and Environmental Science, McGill University, 21,111 Lakeshore Road, Ste-Anne-de-Bellevue, \\ Que. H9X 1CO, Canada
}

\begin{abstract}
Red stele of strawberry (Fragarin $\times$ ananassa Duch.), caused by Phytophthora fragariae, was first observed in Scotland in 1921 (Wardlaw, 1927; Wynn, 1968). The causal agent was named and described by Hickman (1940). The pathogen usually enters through root tips or wounds and invades the stelar root tissue, progressing up to, but not into, the crown of the strawberry plants. Latera1 roots are usually infected first and die, giving a "rat tail" appearance to the root system (Scott et al., 1984). The plants are killed when severely infected by the pathogen. The pathogen spreads mainly via infected roots and possibly field equipment. The disease is of major importance in most countries where temperature and soil moisture conditions are favorable (10 to $15 \mathrm{C}$, wet soil), while it has
\end{abstract} become a limiting factor in some areas.

Pathogenic races of $P$. fragariae were first reported by Scott et al. (1950) and later by Hickman and English (1951). Subsequently, additional races of $P$. fragariae have been reported by other investigators (McKeen, 1958; Montgomerie, 1977; Scott et al., 1950), and the resistance of many cultivars to red stele has been evaluated (Khanizadeh et al., 1991, 1992; Maas, 1976; Maas and Galletta, 1989; Maas et al., 1989; Melville et al., 1980; Scott et al., 1984).

One effective control is the breeding of red stele-resistant varieties. Plant breeders in most strawberry-growing countries are using sources of red stele resistance derived from known genotypes, e.g., 'Sparkle', 'Aberdeen', 'MD683', and 'Stelemaster'. However, little is known of the genetic base of resistance to $P$. fragariae in strawberry. Van de Weg (1989a, 1989b) first identified individual resistance and virulence genes. He reported that the compatible and incompatible interactions between

Received for publication 31 Dec. 1991. Accepted for publication 18 Mar. 1992. The cost of publishing this paper was defrayed in part by the payment of page charges. Under postal regulations, this paper therefore must be hereby marked advertisement solely to indicate this fact.

${ }^{1}$ Research Scientist and Assistant Professor.

${ }^{2}$ Associate Professor and Associate Dean (Academic). the American races $\mathrm{Al}$ to A6, A10, and a British isolate on one hand and the differentials 'Aberdeen', 'Blackemore', 'Climax', 'Del Norte', 'Md 683', 'Perle de Prague', 'Stelemaster', and 'Yaquina A' on the other hand can be described by a gene-for-gene model with five resistance and virulence genes.

Evaluation of strawberry genotypes for susceptibility to $P$. fragariae has been based almost exclusively on visual assessment i.e., reddening of stele in the root (Maas et al., 1989; McKeen, 1958; Melville et al., 1980; Montgomerie, 1966; Otterbacher et al., 1969; Scott et al., 1984), due to its simplicity. However, visual disease assessments for red stele are generally subjective and frequently inconsistent (Milholland et al., 1989). For example, Otterbacher et al. (1969) demonstrated that stelar reddening occurred in roots of both resistant and susceptible strawberry cultivars.

We have shown that resistant cultivars are not immune from infection, and relatively many oospores may be observed in the root tissues of resistant types as well as susceptible genotypes within 6 weeks of inoculation (Khanizadeh et al., 1992). Therefore, while reddening of the stele in field-grown plants may be used as a preliminary diagnostic feature, visual symptoms alone should not be used as a criterion to assess susceptibility (George and Milholland, 1986; Khanizadeh et al., 1992). Genotypes in which the pathogen sporulates to a limited extent in the root may be classified as resistant in genetic studies (Fulton, 1959; Khanizadeh, 1992), but it does not imply that they are not infected.

In many areas of the world, the growers are encouraged to plant runners that are certified as disease free. Despite these measures, outbreaks of disease occur. Difficulty in visually detecting slight infection of plants in propagation beds, and the planting of runners from infected but symptomless resistant cultivars (Fulton, 1959), may contribute toward these outbreaks. Examining the root for the presence of oospores may prove a valuable aid in screening certified strawberry stocks. Although sporulation of the pathogen on and within resistant genotypes is less than in susceptible plants, it may serve to maintain and disperse inoculum in the field and in the soil. This inoculum may be particularly dangerous, as it is produced on resistant plants. A mutant for pathogenicity at the appropriate loci would be ideally situated to spread and infect more tissues.

Strawberry genotypes should not be protected from infection by treating with fungicides, because fungicide residues on the root surfaces could suppress spore germination and infection, thus giving false negative results when the stocks are tested for red stele in the root tip (Duncan, 1985).

Grower's benefit. In breeding trials where infection has been evaluated, no seedling or variety has been found to be completely immune. Thus, the causal organism probably could be spread by infected symptomless roots. Planting stocks should be verified by careful examination of randomly selected roots for the presence of oospores. This relatively simple technique might well be used before planting to monitor the health of commercially distributed daughter plants or certified stocks, especially those of resistant cultivars. Attention should be paid to the term "resistant," which is used widely in horticulture and pathology, i.e., a cultivar described as resistant to $P$. fragariae may not show any symptoms of red stele even though it is infected by the fungus.

\section{Literature Cited}

Duncan, J.M. 1985. Effect of fungicides on survival, infectivity and germination of Phytophthora fragariae oospores. Trans. Brit. Mycol. Soc. 85(4):585-593.

Fulton, R.H. 1959. Spread of strawberry red stele root rot, Phytophthora fragariae, by resistant varieties and survival period of the organism. Plant Dis. Rptr. 43(2):270-271.

George, S.W. and R.D. Milholland. 1986. Inoculation and evaluation of strawberry plants with Phytophthora fragariae. Plant Dis. 70(5):371375 .

Hickman, C.J. 1940. The red core root disease of the strawberry caused by Phytophthora fragariae. J. Pomol. Hort. Sci. 18:89-118.

Hickman, C.J. and M.P. English. 1951. The suscep- 
tibility of strawberry varieties to red core. Trans. Brit. Mycol. Soc. 34:356-359.

Khanizadeh, S., D. Buszard, M. Lareau, and R. Pelletier. 1991. Evaluation of strawberry cultivars with different degrees of resistance to red stele. Fruit Var. J. 45(1):12-17.

Khanizadeh, S., R. Pelletier, M.J. Lareau, D. Buszard, and M. Beauregard. 1992. Field evaluation of fourteen strawberry genotypes in Quebec and their resistance to ten races of Phytophthora fragariae. J. Small Fruit Viticult. (In press).

Maas, J.L. 1976. Red stele disease of strawberry: Soil $\mathrm{pH}$, pathogen, and cultivar interaction. HortScience 11:258-260.

Maas J.L. and G.J. Galletta. 1989. Germplasm evaluation for resistance to fungus-induced diseases. Acta Hort. 265:461-472.

Maas, J.L., G.J. Galletta, and A.D. Draper. 1989. Resistance in strawberry to races of Phytophthora fragariae and to isolates of verticillium from North America. Acta Hort. 265:521-526.
McKeen, W.E. 1958. Races of and resistance to Phytophthora fragariae. Plant Dis. Rptr. 42:768 771 .

Melville, A.H., A.D. Draper, and G.J. Galletta. 1980. Transmission of red stele resistance by inbred strawberry selections. J. Amer. Soc. Hort. Sci. 105:608-610.

Milholland, R.D., W.O. Cline, and M.E. Daykin. 1989. Criteria for identifying pathogenic races of Phytophthora fragariae on selected strawberry genotypes. Phytopathology 79(5):535-538.

Montgomerie, I.G. 1966. Pathogenicity of British isolates of Phytophthora fragariae and their relationship with American and Canadian races. Trans. Brit. Mycol. Soc. 50:57-67.

Montgomerie, LG. 1977. Red core disease of strawberry. Hort. Rev. no. 5. Cmwlth. Agr. Bureaux, F. Royal, United Kingdom.

Otterbacher, A.G., O. Poweli, and C.C. Zych. 1969. The induction of stelar reddening in strawberry roots. Plant Dis. Rptr. 53:794-797.
Scott, D.H., A.D. Drapper, and G.J. Galletta. 1984 Breeding strawberries for red stele resistance. Plant Breeding Rev. 2:195-213.

Scott, D.H., W.E. Jefers, G.M. Darrow, and D.P. Ink. 1950. Occurrence ofstrains of the strawberry red stele fungus, Phytophthora fragariae Hickman as shown by differential varietal response. Phytopathology 40:194-198.

Van de Weg, W.E. 1989a. Genetics of resistance to Phytophthora fragarae Hickman in strawberry. Acta Hort. 265:143-148.

Van de Weg, W.E. 1989b. Cultivar-race interactions of the strawberry-Phytophthora fragariae system with regard to a gene-for-gene model. Acta Hort. 265:203-206.

Wardlaw, C.W. 1927. The strawberry disease in Lanarkshire. Ann. Applied Biol. 14:197-201.

Wynn, W.K. 1968. Development of controlled conditions for the study of red stele disease of strawberries. Contrib. Boyce Thompson Inst 24:95-102. 